Rev. Bras. Reprod. Anim., v.44, n.4, p.159-167, out./dez. 2020

\title{
Use of endometrial vascular perfusion by color Doppler, B-mode ultrasonography and cytology for diagnosis of subclinical endometritis in Holstein cows. \\ Uso da perfusão vascular endometrial por Doppler colorido, ultrassonografia modo B e citologia no diagnóstico de endometrite subclínica em vacas da raça Holandesa.
}

\author{
Fabiani Coutinho Lordão Guido ${ }^{1}$, Sebastião Inocêncio Guido ${ }^{2}$, Joaquim Evêncio Neto ${ }^{1}$ \\ ${ }^{1}$ Federal Rural University of Pernambuco - UFRPE, National Council for Scientific and Technological Development \\ - CNPq, Recife, Pernambuco, Brazil \\ ${ }^{2}$ Agronomic Institute of Pernambuco - IPA, São Bento do Una, Pernambuco, Brazil
}

\begin{abstract}
The aim was to evaluate the use of ultrasonography color Doppler mode for diagnosis the subclinical endometritis (SE) in dairy cows. Lactating Holstein cows on a semi intensive system were evaluated $(n=152)$ and distributed into two groups $(\mathrm{C} 1$ and $\mathrm{C} 2)$. The $\mathrm{C} 1(\mathrm{n}=60)$ was composed of primiparous and the $\mathrm{C} 2(\mathrm{n}=92)$ by pluriparous. All females $(\mathrm{C} 1$ and $\mathrm{C} 2)$ were submitted gynaecological examination by transrectal palpation and evaluation with the Metricheck device (MD) and endometrial cytology (EC) to determine the percentage of neutrophils (PMNs). Ultrasonographic examinations were performed in the B mode for the presence of echogenic intrauterine fluid (IUF-e) and for color Doppler mode endometrial vascular perfusion evaluation (ENDOVP). Data were submitted to ANOVA with Pearson correlation and chi-square test at $5 \%$. In the evaluation with MD, $16.7 \%$ of the cows in the $\mathrm{C} 1$ and $17.4 \%$ in the $\mathrm{C} 2$ were considered inapt. Regarding SE prevalence was $24.0 \%(\mathrm{C} 1)$ and $44.7 \%(\mathrm{C} 2)$. As far as the ultrasound evaluation of the IUF-e was present in $68.0 \%$ of the cows of the $\mathrm{C} 1$ and in $75.0 \%$ in the C2. In the ENDOVP, scores 1 (38.0\%), 2 (36.5\%), 3 (23.0\%) and 4 (8.7\%) were evidenced. There was a correlation between ENDOVP and PMN in $\mathrm{C} 1(\mathrm{r}=0.8336)$ and in $\mathrm{C} 2(\mathrm{r}=0.7196)$. Therefore, it is concluded that ENDOVP proved to be efficient for the diagnosis of SE, in view of its strong correlation with PMN.
\end{abstract}

Keywords: cattle, endometritis, vaginal mucus, ultrasound, Doppler.

\section{Resumo}

O objetivo foi avaliar o uso da ultrassonografia no modo Doppler colorido para o diagnóstico da endometrite subclínica (ES) em vacas leiteiras. Vacas da raça Holandesa foram avaliadas $(n=152)$ em lactação e mantidas em sistema semi-intensivo. Elas foram distribuidas em dois grupos ( $\mathrm{Cl}$ e C2). $\mathrm{O}$ $C 1(n=60)$ foi composto por primíparas e o C2 $(n=92)$ por pluriparas. Todas as vacas $(C 1$ e C2) foram submetidas a exame ginecológico por palpação transretal e avaliação com o dispositivo Metricheck (DM). Depois, amostras foram coletadas para citologia endometrial (CE) para determinar a porcentagem de neutrófilos (PMNs). Os exames ultrassonográficos foram realizados no modo B para a presença de líquido intra-uterino ecogênico (IUF-e) e para avaliação da perfusão vascular endometrial no modo Doppler colorido (ENDOVP). Os dados foram submetidos à ANOVA com correlação de Pearson e teste do qui-quadrado a 5\%. Na avaliação com DM, 16,7\% das vacas no C1 e 17,4\% no C2 foram consideradas inaptas. Em relação a prevalência de ES, foi de 24,0\% (C1) e 44,7\% (C2). Quanto à avaliação ultrassonográfica do IUF-e, esteve presente em $68,0 \%$ das vacas do Cl e em 75,0\% no C2. Na avaliação da ENDOVP, foram evidenciados os escores 1 (38,0\%), 2 (36,5\%), 3 (23,0\%) e $4(8,7 \%)$. Houve correlação entre ENDOVP e PMN no C1 $(r=0,8336)$ e no C2 $(r=0,7196)$. Portanto, conclui-se que a ENDOVP se mostrou eficiente para o diagnóstico de ES, tendo em vista sua forte correlação com os PMN.

Palavras-chave: bovino, endometrite, muco vaginal, ultrassom, Doppler.

\section{Introduction}

In dairy herds, reproductive efficiency is essential for high productivity. However, correlations between reproductive traits and milk production indicate that productivity is phenotypically and

Correspondência: fclordao@uol.com.br Recebido: 26 de junho de 2020

Aceito: 03 de agosto de 2020 
Guido et al. Use of endometrial vascular perfusion by color Doppler, B-mode ultrasonography and cytology for diagnosis of subclinical endometritis in Holstein cows.

genetically associated with reduced reproductive efficiency in dairy cows (Nebel and McGilliard, 1993). In this context, the use of efficient methods of diagnosis of reproductive disorders, can contribute significantly to reach good reproductive efficiency indices (Guido et., 2017; Guido et al., 2019). Clinical endometritis is one of the main disorders reported in dairy cattle, with prevalence varying from $7.6 \%$ (Guido et al., 2016) to 53\% (Gilbert et al., 2005). This wide variation in prevalence is associated with inconsistencies in diagnostic methods and, mainly, differences between herds (Boer et al., 2014). Despite subclinical endomentritis, it causes significant losses with reduced reproductive performance, possibly due to the low importance given to its diagnosis, prevalences close to $40 \%$ are reported in some herds (Opsomer, 2015). Perhaps, the laborious diagnosis of subclinical endometritis by traditional methods, such as endometrial cytology (Kasimanickam et al., 2004, Couto et al., 2013, Boer et al., 2014) may contribute to poor utilization of routine reproductive in cattle. Nevertheless, ultrasound has contributed to the advances of the reproductive evaluation of animals of production, being applied in the evaluation of the physiological and pathological processes (Ginther, 2014; Viana and Siqueira, 2017). The Doppler evaluation was also applied to the study of the blood flow of the genital organs of cattle, investigating the physiological changes in different phases of the estrous cycle (Herzog and Bollwein, 2007). Specifically, in the evaluation of blood flow of uterine arteries during pregnancy (Bollwein et al., 2002) and the puerperium (Heppelmann et al., 2013). It should still be considered that inflammatory processes evidence increased blood flow in the uterus and that color mode is the most appropriate technique to evaluate this flow (Debertolis et al., 2016). However, it has not yet been associated with the diagnosis of subclinical endometritis in cows. Therefore, the objective of this study was to evaluate the use of color Doppler ultrasonography to establish a diagnostic standard for subclinical endometritis in dairy cows.

\section{Material and Methods}

This study was conducted at the Experimental Station of São Bento do Una (ESSBU), belonging to the Agronomic Institute of Pernambuco - IPA, located in São Bento do Una, Pernambuco, Brazil, latitude 0831 ' $35^{\prime}$ 'S, longitude $03627^{\prime} 34,8$ 'W and temperature and humidity index (THI) of 69.4 for the period. Holstein cows $(n=152)$ were evaluated, with ages ranging from 24 to 120 months and mean of 46 days in milk (DIM), with daily production being measured. The cow's body condition score (BCS) was evaluated according to the scale of 1 to $5(1=$ very lean and $5=$ obese $)$, proposed by Edmonson et al. (1989). All animals were kept in a semi-intensive system, receiving a diet composed of spineless cactus (Opuntia stricta [Haw]. Haw), sorghum silage (Sorghum bicolor [L.] Moench) and concentrate containing $24 \%$ crude protein and $1.5 \%$ of mineral supplement, in addition to mineral supplement and water ad libitum.

After an average voluntary waiting period of 46 days, the cows were distributed in two experimental groups $(\mathrm{C} 1$ and $\mathrm{C} 2)$. The $\mathrm{C} 1(\mathrm{n}=60)$ consisted of primiparous and $\mathrm{C} 2(\mathrm{n}=92)$ by pluriparous. All cows from both groups $(\mathrm{C} 1$ and $\mathrm{C} 2)$ were submitted to cyclical monitoring and gynecological examination. Initially, those considered cyclical were submitted to evaluation of the vaginal mucus with the aid of the Metricheck Device (MD), with scores of 0-3 being assigned according to Williams et al. (2005). Cows evaluated with a score of 3 were considered inapt. The procedure was performed according to Guido et al. (2017), where prior to the use of the device, previous cleaning of the vulva with running water was carried out, followed by the topical application of iodopolvidone degerming and drying with paper towel. The MD was inserted after opening the vulvar lips, advancing cranially to the vaginal fornix, and drawn caudally. After use, the MD was disinfected with dichloroisocyanurate solution (Agrisept ${ }^{\circledR}$ MC Tabs) and immediately prior to use a wash of the device with $0.9 \%$ saline solution was preceded for each cow examined.

Immediately after the evaluation with the MD, the samples were collected for endometrial cytology (EC) using a disposable endometrial brush (cytobrush) for human use, coupled with an applicator for artificial insemination in bovine with sheath, protected by sanitary dressing. Initially, the vulva was washed with running water, followed by drying with paper towel. After the material was harvested, the cytologic smear were prepared and stained by the Diff-Quik method (Peleteiro et al., 2011). After drying the blades, the endometrial cytology was analyzed using a binocular microscope from a 100 cell count to determine the percentage of neutrophils. A $100 \mathrm{X}$ objective was used, traversing the zig zag blade, taking ten microscopic fields from the regions with the highest cell concentration (Peleteiro et al., 2011).

After collecting the cytological samples, the monitoring of metabolic disorders was performed in all cows of both groups $(\mathrm{C} 1$ and $\mathrm{C} 2)$ through the evaluation of the blood concentrations of $\beta$ - 
Guido et al. Use of endometrial vascular perfusion by color Doppler, B-mode ultrasonography and cytology for diagnosis of subclinical endometritis in Holstein cows.

Hydroxybutyrate (BHB) using the Ketovet $^{\circledR}$ electronic meter, being considered as cutoff the concentration of $1.2 \mathrm{mmol} / \mathrm{mL}$ according to Iwersen et al. (2013). For the analysis, local antisepsis was performed at the tail end of each animal and punctured was did with a sterile needle, the end of the reading tape was placed on the blood drop and the result obtained in 5 seconds.

The plasma levels of plasmatic fibrinogen (PF) and total leukocytes in $50 \%$ of the cows of both groups $(\mathrm{C} 1$ and $\mathrm{C} 2)$ were determined by collecting a blood sample in a $4 \mathrm{~mL}$ vacuum tube containing ethylene diamine tetracetate (EDTA-K3) at $15 \%$, collected immediately after BHB monitoring. The samples were then stored under refrigeration and transported to the clinical pathology laboratory of the Cattle Clinic of UFRPE to perform the tests according to Jain (1993).

Ultrasound imaging (Mindray M-5®) equipped with a linear endorectal transducer at $6.0 \mathrm{MHz}$ was used. The cows were initially evaluated in the B mode for the presence of echoic intrauterine fluid (IUF-e), with scores ranging from 0 to 2 according to Ginther (1998). Following the use of color Doppler mode, the evaluation of endometrial vascular perfusion (ENDOVP) was performed in the longitudinal sagittal plane of the middle third of both uterine horns, with scores of 1 to 4 being attributed according to Ginther (2007). The examinations were performed by the same operator and the images stored in the machine's memory and subsequently evaluated by two qualified technicians.

After the evaluations, all cows from both experimental groups ( $\mathrm{C} 1$ and $\mathrm{C} 2)$ were submitted to fixed-time artificial insemination (FTAI) protocol according to Guido et al. (2012). The protocol was started on day 0 (D0), where all cows received an intravaginal implant containing $1.9 \mathrm{~g}$ of progesterone and $2 \mathrm{mg}$ of estradiol benzoate (EB). On day 7 (D7) the application of 1,060 $\mathrm{mg}$ of cloprostenol sodium and $400 \mathrm{IU}$ eCG, on day 8 (D8) the intravaginal implant was withdrawn. After 24 (D9) and 54 hours (D10), respectively, $1 \mathrm{mg}$ BE was injected and FTAI was performed on all cows. Later, on the 30th day after FTAI, they were submitted to the diagnosis of pregnancy through transrectal palpation assisted by ultrasonography. Cows of both groups $(\mathrm{C} 1$ and $\mathrm{C} 2)$ that repeated estrus at regular intervals after FTAI were again inseminated in the second and third estrus, constituting the subgroups AI1, AI2 and AI3. Three services were considered in the protocol for the cows they conceived.

Data were submitted to analysis of variance ANOVA with the Pearson correlation with significance level of $5 \%$ for variables: daily milk production, vaginal mucus score with DM, intrauterine secretion score on B mode ultrasonography, perfusion score uterine vasculature in color Doppler mode, BHB, FP and leukogram. As well as, the chi-square test at 5\% for the design proportions the FTAI according to the ENDOVP score. Being used for the analysis the computational program BioEstat version 1998.

The experiment was submitted to and approved $\left(n^{\circ}\right.$ 092/2017) by the Ethics Committee on the Use of Animals (ECUA) at UFRPE.

\section{Results and Discussion}

The cows evaluated in this study had a mean BSC of 2.3 for both groups ( $\mathrm{C} 1$ and $\mathrm{C} 2)$. The average daily production of milk was $20.6 \mathrm{~kg}$ in $\mathrm{C} 1$, being lower $(\mathrm{P}<0.05)$ than the $23.7 \mathrm{~kg}$ recorded in C2. C2 was expected to be cows with more than one calving, according to Bjelland et al. (2011).

In the evaluation of vaginal mucus score with $\mathrm{MD}, 10(16.7 \%)$ cows in $\mathrm{C} 1$ and $16(17.4) \%$ in $\mathrm{C} 2$, that is, those with mucus with score 3 (Figure 1) were considered inapt, characterizing a clinical endometritis table according to Guido et al. (2017). These same authors diagnosed $7.6 \%$ of the cows with endometritis, when they had purulent or bloody discharge on examination with MD. Results below the $47.5 \%$ reported by Pleticha et al. (2009) when using the same diagnostic method. Influence of the animal category $(\mathrm{P}>0.05)$ on the mucus score was not verified, with the highest prevalence for scores $1(36.7 \%$ in $\mathrm{C} 1$ and $36.9 \%$ in $\mathrm{C} 2$ ) and 2 (26.7\% in $\mathrm{C} 1$ and $27.2 \%$ in $\mathrm{C} 2)$. However, the method may be an important screening tool for cows in reproductive programs, but with moderate specificity, as reported by McDougall et al. (2007). Considering that even cows with a score of 1 and 2 had no detriment to conception at first insemination (Figure 2), an event also described by Pleticha et al. (2009) and Guido et al. (2017). Probably, this is due to the fact that the method does not differentiate the origin of the mucus, either vaginal or endometrial. Being susceptible to the occurrence of vaginitis and not of endometritis in the cows, especially considering that in this study there was no correlation between endometrial cytology (EC) and the results obtained with MD in both groups $\mathrm{C} 1(\mathrm{r}=-0.0387)$ and $\mathrm{C} 2(\mathrm{r}=-0.0161)$. Although most of the cows evaluated with MD presented some alteration in mucus appearance (Figure 1). Certainly, as occurs in vaginoscopy that does not allow detection of uterine discharge in cows with closed cervix (Kasimanickam et al., 2004), MD may also present this limitation. 
Guido et al. Use of endometrial vascular perfusion by color Doppler, B-mode ultrasonography and cytology for diagnosis of subclinical endometritis in Holstein cows.

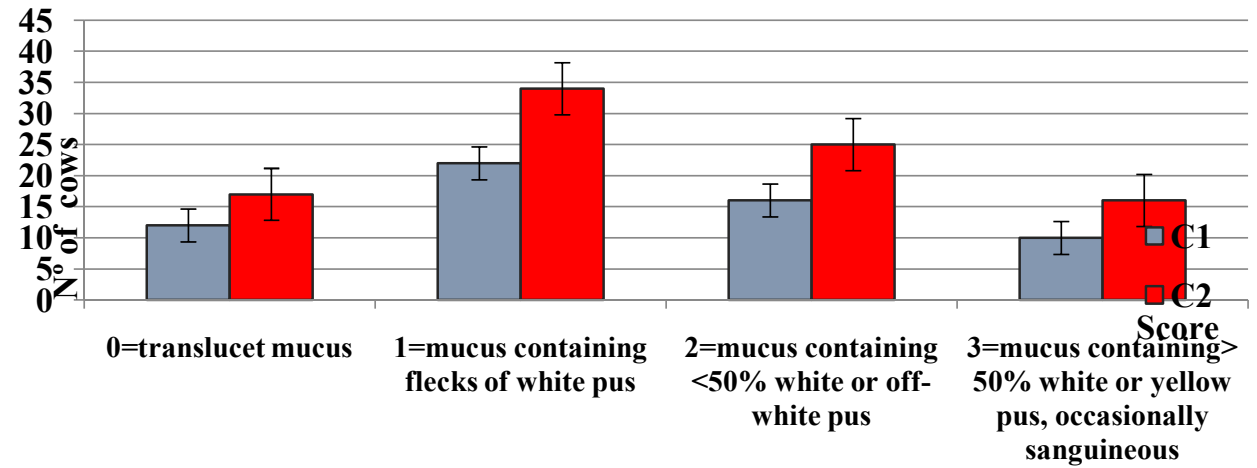

Figure 1. Distribution of the vaginal mucus score evaluated with Metricheck ${ }^{\circledR}$ Device (MD) in Holstein cows according to category, primiparous $(\mathrm{C} 1)$ and pluriparous $(\mathrm{C} 2) .(\mathrm{P}>0.05)$.

Regarding the EC results, the occurrence of subclinical endometritis (SE) was observed in $24.0 \%$ of the $\mathrm{C} 1$ cows and $44.7 \%$ of the $\mathrm{C} 2$ cows (Table 1), considering the reference value for the evaluation period of the cows, that is, greater than $10 \%$ of neutrophils in the sample, according to Kasimanickam et al. (2004) and Cheong et al. (2011). The results observed in C1 corroborate those reported by Meira et al. (2012) with the occurrence in $21 \%$ of subclinical endometritis and are lower than those reported by Kasimanickam et al. (2004) in a similar period of evaluation using the EC as diagnostic standard.

Considering that neutrophils constitute the first local line of defense, resulting in an increase in uterine polymorphonuclear cells (Butt et al., 1993) and that EC is the main method of diagnosis of subclinical endometritis (Gilbert et al., 2005; Galvão et al., 2009). The results of this study show this affirmation, mainly for the category of pluriparous cows (Table 1). However, it should be evaluated that despite high specificity, as recorded by Kasimanickam et al. (2004), the method demonstrates little practicality and high time dispensed to obtain the results. The one that of more than predisposes the permanence of cows without diagnosis of the uterine conditions and presenting low rate of conception. However, no method of diagnosis of endometritis is $100 \%$ sensitive when evaluating reproductive performance (Kasimanickam et al., 2004). As well, one should opt for the association of diagnostic methods as a more viable alternative to approach reproductive disorders (Martins et al., 2013).

Associating other indicators that support the diagnosis of reproductive disorders such as subclinical endometritis in cattle has demanded the dedication of research groups (Kasimanickam et al., 2004, Madoz et al., 2014). Therefore, in this study, the determination of hematological parameters of plasma fibrinogen (PF) and total leukocytes (LT), as well as blood BHB dosage with metabolic indicator was performed, with no difference $(\mathrm{P}>0.05)$ for the parameters (Table 2). Mean values were obtained for FP of 528 and $540 \mathrm{mg} / \mathrm{dL}$ in cows negative for subclinical endometritis in $\mathrm{C} 1$ and $\mathrm{C} 2$ respectively. However, slightly lower values occurred in SE positive cows, where averages of 412 and $479 \mathrm{mg} / \mathrm{dL}$ were observed in the $\mathrm{C} 1$ and $\mathrm{C} 2$ cows, respectively. Therefore, values for FP are higher than those found by Kaneko et al. (2008). Differing from those found by Silva et al. (2008), which obtained an average value of $633 \mathrm{mg} / \mathrm{dL}$ for Nellore cattle. The same occurred with LT with positive cows SE presented slightly higher values than negative, but within the expected (Table 2). Possibly, by ES if it is a local inflammatory process there is no change in the hematological profile of the affected animal.

Regarding the BHB, no statistical difference was obtained between the groups studied, although the values observed for SE positive animals according to EC were above the cutoff point for BHB dosage. The $\mathrm{C} 1$ presented concentrations that according to Geishauser et al. (2000) and Guido et al. (2019) are below those considered as indicative for subclinical ketosis $(>1.4 \mathrm{mmol} / \mathrm{L})$. High concentrations of BHB may compromise the physiological functions of organs due to their toxicity (Bode et al., 2004). The concentrations found differ from those of Alvarenga et al. (2015), where the mean postpartum was 0.62 $\mathrm{mmol} / \mathrm{L}$, at 21 days in lactation, but are in agreement with Fiorentin et al. (2017), where the average found was $1.14 \mathrm{mmol} / \mathrm{L}$, at 30 DIM. As well as the concentrations obtained by Lomander et al. (2012), where cows that had delayed the first insemination after calving, found a mean concentration of $1.0 \mathrm{mmol}$ / L. 
Guido et al. Use of endometrial vascular perfusion by color Doppler, B-mode ultrasonography and cytology for diagnosis of subclinical endometritis in Holstein cows.

Table 1. Occurrence of subclinical endometritis evaluated with endometrial cytology in Holstein cows of different categories: primiparous $(\mathrm{C} 1)$ and pluriparous $(\mathrm{C} 2)$.

\section{Endometrial cytology}

N (\%)

\begin{tabular}{lccc}
\hline \multicolumn{1}{c}{ Group } & n & Neutrophils $<\mathbf{1 0}$ & Neutrophils $>\mathbf{1 0}$ \\
\hline C1 - Primiparous & 50 & $38 / 50(76.0)$ & $12 / 50(24.0)^{\mathrm{a}}$ \\
C2 - Pluriparous & 76 & $42 / 76(55.3)$ & $34 / 76(44.7)^{\mathrm{b}}$
\end{tabular}

${ }^{\mathrm{a}, \mathrm{b}}$ Means difference between categories $\mathrm{P}<0,05$

Table 2. Plasmatic fibrinogen, leukocytes and $\beta$-hydroxybutyrate in Holstein cows of different categories, negative (NEG) or positive (POS) for subclinical endometritis.

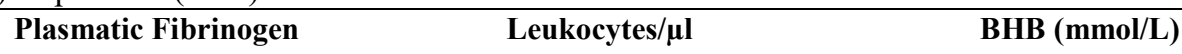

$(\mathbf{m g} / \mathrm{dL})$

\begin{tabular}{|c|c|c|c|c|c|c|c|}
\hline Group & $\mathbf{n}$ & NEG & POS & NEG & POS & NEG & POS \\
\hline $\mathrm{C} 1$ & 25 & $528 \pm 292$ & $412 \pm 124$ & $14928 \pm 3587$ & $13481 \pm 2647$ & $0,88 \pm 0,41$ & $1,6 \pm 0,57$ \\
\hline $\mathrm{C} 2$ & 38 & $540 \pm 168$ & $479 \pm 169$ & $16670 \pm 4290$ & $14537 \pm 5820$ & $1,2 \pm 0,81$ & $1,5 \pm 0,68$ \\
\hline
\end{tabular}

$\mathrm{P}>0,05$

As for the ultrasound evaluation of mode B for the presence of echoic intrauterine secretion, according to the criteria established by Ginther (1998), the results showed in this study an occurrence of IUF-e and $68.0 \%$ of $\mathrm{C} 1$ and 75 cows, $0 \%$ in $\mathrm{C} 2$. This reinforces the subjectivity of the determination of intrauterine fluid by conventional ultrasound in the diagnosis of endometritis, considering that in endometrial cytology the occurrence of endometritis was lower for both groups (Table 1), although some authors consider the method to be reliable (Mateus et al., 2002). Though, only the measurement of uterine structures is generally associated with establishing the diagnosis (Meira et al., 2012). However, without specifying the echogenicity characteristics of this fluid, as proposed in this study.

In the color Doppler evaluation to determine the endometrial vascular perfusion score (ENDOVP), the criteria established by Ginther (2007) were considered, and the scores from 1 to 4 were evidenced (Figure 2). A score of 1 (31.7\%), 2 (36.5\%), $3(23.0 \%)$ and $4(8.7 \%)$ were recorded in the cows evaluated in this study $(\mathrm{C} 1$ and $\mathrm{C} 2)$.

The evaluation of the vascular perfusion of the endometrium was indirectly associated with the inflammatory response in beef cows after FTAI, a procedure such as uterine biopsy or induced endometritis (Pugliesi et al., 2014; Oliveira et al., 2014; Debertolis et al., 2016). However, its applicability to the routine of reproductive follow-up in dairy cattle by field technicians has not yet been established. Although the uterine vascular flow in cattle presented changes during the experimental induction of endometritis (Debertolis et al., 2016). It is therefore necessary to establish a standard diagnostic for reproductive disorders such as SE, objective of this study. In particular, considering the positive association between vascular perfusion and events in which there is increased blood flow in the reproductive tract (Jordan et al., 2009).

Therefore, there was a strong correlation between ENDOVP and the percentage of PMN neutrophils (Tables 3 and 4) for the cows examined in the two groups (C1 and $\mathrm{C} 2$ ), supporting their use in the diagnosis of SE in dairy cows. These results confirm the findings of Debertolis et al. (2016) who, using Doppler ultrasound, showed an increase in uterine blood flow in cows subjected to induced endometritis. However, these authors used the spectral mode to evaluate the parameters of the uterine arteries. Different the present study, in which the color mode was used, indicating perfusion scores, according to Ginther (2007). 
Guido et al. Use of endometrial vascular perfusion by color Doppler, B-mode ultrasonography and cytology for diagnosis of subclinical endometritis in Holstein cows.

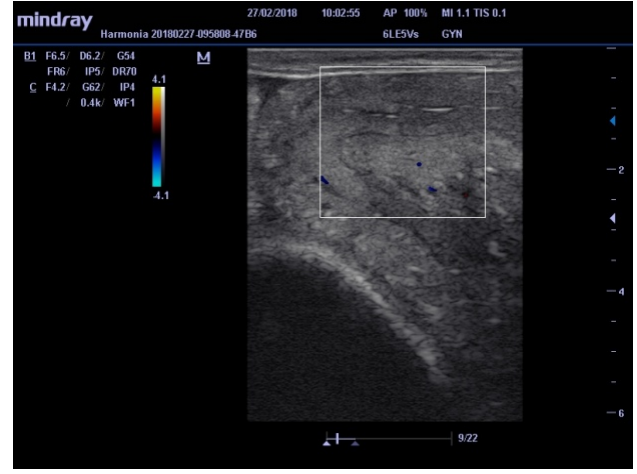

Score 1

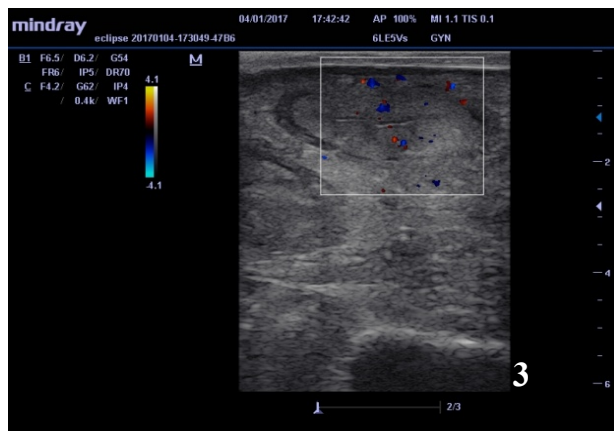

Score 3

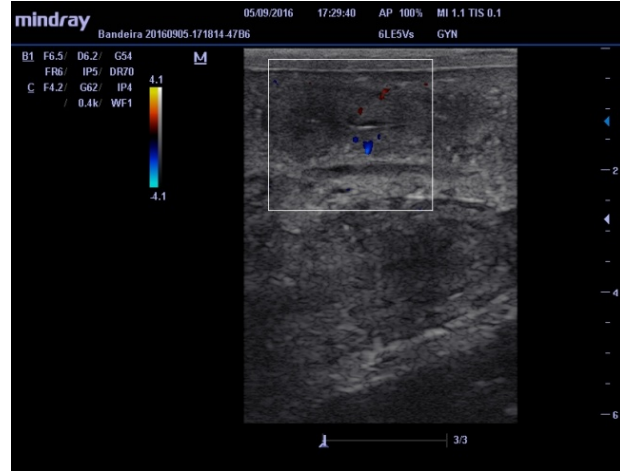

Score 2

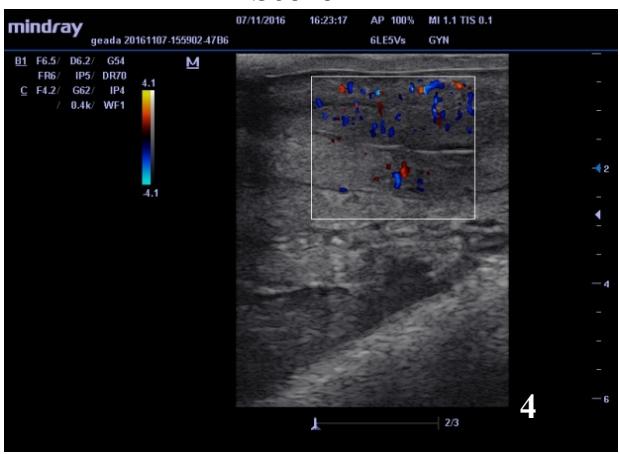

Score 4

Figure 2. Endometrial vascular perfusion scores evaluated with color Doppler in Holstein cows according to category, primiparous $(\mathrm{C} 1)$ and pluriparous $(\mathrm{C} 2)$.

Table 3. Correlation between diagnostic parameters of subclinical endometritis in primiparous (C1) Holstein cows.

\begin{tabular}{|c|c|c|c|c|c|c|c|}
\hline Parameters & Fibrinogen & Leukocytes & PMN\% & MD & BHB & IUF-e & ENDOVP \\
\hline Fibrinogen & 1 & & & & & & \\
\hline Leukocytes & $0.6065(*)$ & 1 & & & & & \\
\hline PMN\% & -0.2604 & -0.1676 & 1 & & & & \\
\hline MD & -0.0887 & -0.1465 & -0.0387 & 1 & & & \\
\hline BHB & 0.0046 & -0.0755 & 0.2181 & $0.3373\left(^{*}\right)$ & 1 & & \\
\hline IUF-e & 0.0968 & 0.0121 & 0.1793 & 0.1943 & 0.2831 & 1 & \\
\hline ENDOVP & -0.1642 & -0.3520 & $0.8336(* *)$ & -0.0830 & $0.4648(* *)$ & $0.3693(* *)$ & 1 \\
\hline
\end{tabular}

Table 4. Correlation between diagnostic parameters of subclinical endometritis in pluriparous (C2) Holstein cows.

\begin{tabular}{lrrrrrrr}
\hline Parameters & Fibrinogen & Leukocytes & PMN\% & MD & BHB & IUF-e & ENDOVP \\
\hline Fibrinogen & 1 & & & & & & \\
Leukocytes & 0.2689 & 1 & & & & & \\
PMN\% & -0.0986 & -0.1368 & 1 & & & & \\
MD & 0.1797 & 0.0010 & -0.0161 & 1 & & & \\
BHB & -0.1129 & 0.0664 & 0.1646 & 0.1793 & 1 & & \\
IUF-e & 0.0757 & -0.1602 & 0.1117 & 0.0959 & 0.1055 & 1 & \\
ENDOVP & 0.0000 & -0.0569 & $0.7196\left(^{* *}\right)$ & 0.0261 & 0.0758 & $0.2527(*)$ & 1 \\
\hline Significance levels with $(\mathrm{n}-2)=74 \mathrm{~g}$ values of "r" at $5 \%=0.2257(*)$ and $1 \%=0.2938(* *)$. &
\end{tabular}


Guido et al. Use of endometrial vascular perfusion by color Doppler, B-mode ultrasonography and cytology for diagnosis of subclinical endometritis in Holstein cows.

It is also pertinent to point out that, in addition to not being an invasive method, ultrasound diagnosis can be established in real time, considering that in this study the evaluations of ENDOVP were performed in up to $20 \mathrm{~min}$ for each cow, corroborating the work of Heppelmann et al. (2013) that even evaluating the flow of the uterine artery in spectral Doppler mode took only 30 min per cow. In addition to allowing greater selection criterion for cows destined to reproductive programs, as recommended by Jordan et al. (2009) and Pugliesi et al. (2017).

Regarding the results obtained, the ENDOVP evaluation proved to be efficient in the selection of cows for the IATF programs, considering that the animals with the lowest ENDOVP score presented higher pregnancy results $(\mathrm{P}<0.05)$. However, if we take into account that, in this study, the conception rate was also higher $(\mathrm{P}<0.05)$ in the first insemination (AI1), even in cows with score 2 in ENDOVP (Figure 3), certainly the IATF protocol contributed to the results. These results corroborate those obtained by Guido et al. (2018) with a conception rate of $59.6 \%$ in primiparous women and $44.7 \%$ in pluriparous women of the same race, kept under the same conditions.

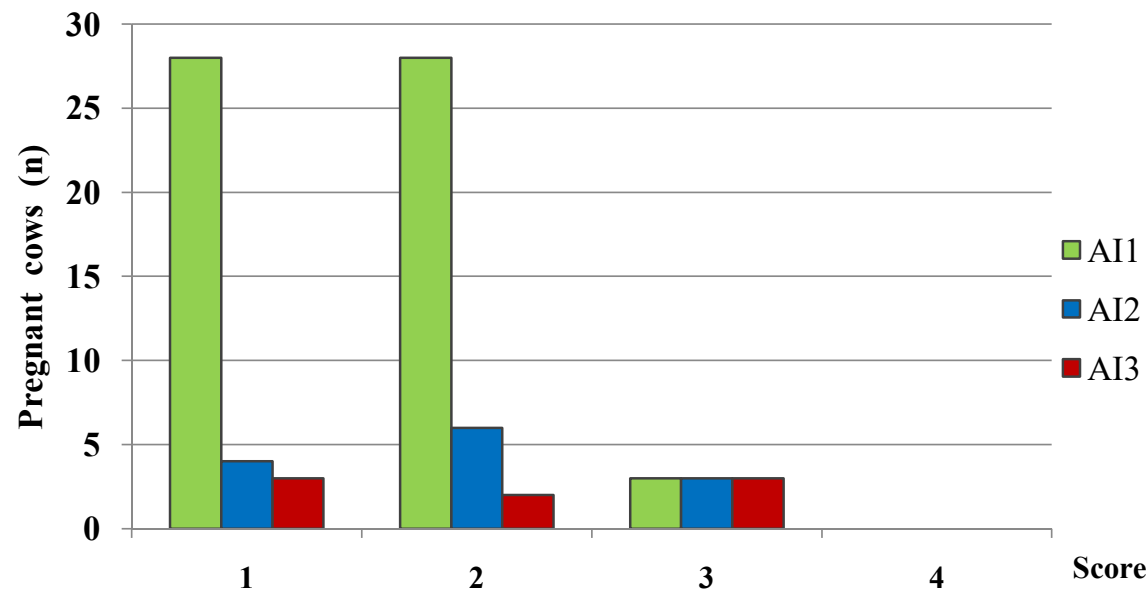

Figure 3. Distribution of the conception according to the ENDOVP score in color Doppler mode and the order of artificial insemination in Holstein cows. $\mathrm{P}<0.05$.

\section{Conclusion}

In conclusion, the evaluation with MD can be used to screen cows with clinical endometritis. Subclinical endometritis was more prevalent in pluriparous. In addition, the use of color Doppler ultrasonography to obtain the endometrial perfusion score proved to be efficient for the diagnosis of subclinical endometritis in dairy cows, considering its strong correlation with PMNs.

\section{Acknowledgments}

This study was generously supported by the National Council for Scientific and Technological Development - CNPq (Brasília, Brazil) and the Agronomic Institute of Pernambuco - IPA (São Bento do Una, Pernambuco, Brazil).

\section{References}

Alvarenga EA, Moreira GHFA, Facury Filho EJ, Leme FOP, Coelho SG, Molina LR, Lima JAM, Carvalho AU. Avaliação do perfil metabólico de vacas da raça Holandesa durante o período de transição. Pesq Vet Bras, v.35, n.3, p.281-290, 2015.

Bjelland DW, Weigel KA, Hoffman PC, Esser NM, Cobletz WK, Halbach TJ. Production, reproduction, helth, and growth traits in backcross Holstein $\mathrm{x}$ Jersey cows and their Holstein contemporaries. J Dairy Sci, v.94, n.10, p.5194-5203, 2011.

Bode G, Young JW, Beitz DC. Invited review: pathology, etiology, prevention and treatment of fatty liver in dairy cows. J Dairy Sci, n.87, n.10, p.3105-3124, 2004. 
Guido et al. Use of endometrial vascular perfusion by color Doppler, B-mode ultrasonography and cytology for diagnosis of subclinical endometritis in Holstein cows.

Boer MW, LeBlanc SJ, Dubuc J, Meier S, Heuwieser W, Arit S Gilbert RO McDougall S. Invited review: Systematic review of diagnostic tests for reproductive-tract infection and inflammation in dairy cows. J Dairy Sci, v.97, n.7, p.3983-3999, 2014.

Bollwein H, Baumgartner U, Stolla R. Transrectal Doppler sonography of uterine blood flow in cows during pregnancy. Theriogenology, v.57,n.8, p.2053-2061, 2002.

Butt BM, Senger PL,.Widders PR. Neutrophil migration into bovine uterine lumen following intrauterine inoculation with killed Haemophilus somnus. J Reprod Fert, v.93, p.341-345, 1993.

Cheong SH, Nydam DV, Galvão KN, Crosier BM, Gilbert RO. Cow level and herd-level risk factors for subclinical endometritis in lactation Holstein cows. J Dairy Sci, v.94, n.2, p.762-770, 2011.

Couto GB, Vaillancourt DH, Lefebvre RC. Comparison of a leukocyte esterase test with endometrial cytology for diagnosis of subclinical endometritis in postpartum dairy cows. Theriogenology, v.79, n.1, p.103-107, 2013.

Debertolis L, Mari G, Merlo B, Merbach S, Schoon HA, Iacono E, Bollwein H. Effects if induced endometritis on uterine blood flow in cows as evaluated by transrectal Doppler sonography. J Vet Sci, v.17, n.2, p.189-197, 2016.

Edmonson A.J., Lean, I.J., Weaver, L.D., Farver, T., Webster, G. A body condition scoring chart for Holstein dairy cows. J Dairy Sci, v.2, n.1, p.8-78, 1989.

Fiorentin E, Tiecher A, Menegat C, Soares C, Aires A, Rocha R, Gonzalez FHD. Accuracy of two hand-held eletronic devices for determinations of blood $\beta$-hydroxybutyrate in dairy cows. Rev Bras Saúde Prod Anim, v.18, n.3, p.439-445, 2017.

Galvão KN, Frajblat M, Brittin SB, Butler WR, Guarda CL, Gilbert RO. Effect of prostaglandin F2 $\alpha$ on subclinical endometritis and fertility in dairy cows. J Dairy Sci, v.92, n.10, p.4906-4913, 2009.

Geishauser T, Leslie K, Tenhag J, Uma B. Evaluations of eight cow-side ketone tests in milk for detection of subclinical ketosis in dairy cows. J Dairy Sci, v.83, n.2, p.296-299, 2000.

Gilbert RO, Shin ST, Guarda CL, Erb HN, Frajblat M. Prevalence of endometritis and its effects on reproductive performance of dairy cows. Theriogenology, v.64, n.9, p.1879-1888, 2005.

Ginther OJ. Ultrasonic Imaging and Animal Reproduction: Cattle. Wisconsin: Equiservices Publishing 3: p.304, 1998.

Ginther OJ. Ultrasonic Imaging and Animal Reproduction: Color-Doppler Ultrasonography. Wisconsin: Equiservices Publishing 4: p.258, 2007.

Ginther, OJ. How ultrasound technologies have expanded and revolutionized research in reproduction in large animals. Theriogenology, v.81, n.1, p.112-125, 2014.

Guido FCL, Guido SI, Alencar LF, Bartolomeu CC, Evêncio Neto J. Utilização do dispositivo Metricheck e da ultrassonografia para seleção de vacas leiteiras em programas de inseminação artificial em tempo fixo. Rev Bras Reprod Anim, v.41, n.3, p.678-682, 2017.

Guido FCL, Guido SI, Alencar LF, Oliveira JCV, Santos VF, Evêncio Neto J. Efeito da suplementação com ácidos graxos associados à palma forrageira sobre a perfusão vascular endometrial em vacas Holandesas no pós-parto. Pesq. Agropec Pernambucana, v.24, pe2061242019 - 8, 2019.

Guido FCL, Guido SI, Bezerra AR, Evêncio Neto J. Incidência de distúrbios reprodutivos em vacas da raça holandesa criadas em condições de semiárido. Ciênc Vet Tróp, v.19, n.1, p.52-57, 2016.

Guido SI, Guido FCL, Alencar, LF, Azevedo PRL, Oliveira JCV, Santos Filho, AS, Evêncio Neto J. Influence of parity category on conception rate of Holstein females submitted to timed artificial insemination in semiarid conditions. Anim Reprod, v.15, n.1, p.1126, 2018.

Guido SI, Guido FCL, Andrade JCO, Santos Filho AS, Bartolomeu CC. Reproductive efficiency of Holstein cows submited to fixed time artificial insemination in semiarid regions. Reprod Domest Anim, v.47, n.4, p.424, 2012.

Heppelmann M, Krüger L, Stephanie L, Bollwein H. Transrectal Doppler sonography of uterine blood flow during the first two weeks after parturition in Simmenthal heifers. J Vet Sci, v.14, n.3, p.323-327, 2013.

Herzog K, Bollwein H. Application of Doppler Ultrassonography in Cattle Reproduction. Reprod Domest Anim, v.42, n.2, p.51-58, 2007.

Iwersen M, Klein-Jöbstl D, Pichler H, Roland G, Fidlschuster B, Scwendeweun I, Drillich M. Comparison of 2 electronic cowside tests to detect subclinical ketosis in dairy cows and the influence of the temperature and type of blood sample on the test results. J Dairy Sci, v.96, n.12, p.7719-7730, 2013.

Jain NC, Essentials of Veterinary Hematology. Lea and Febinger, Philadelphia, p.417, 1993.

Jordan A, Herzog K, Ulbrich SE, Beindorff N, Honnes Ä, Krüger L, Miyamoto A, Bollwein $H$. 
Guido et al. Use of endometrial vascular perfusion by color Doppler, B-mode ultrasonography and cytology for diagnosis of subclinical endometritis in Holstein cows.

Genital blood flow and endometrial gene expression during the preovulatory period after prostaglandin F2 $\alpha$ - induced luteolysis in different luteal phases in cows. J Reprod Dev, v.55, n.3, p.309-315, 2009.

Kaneko JJ, Harvey JW, Bruss ML. Clinical Biochemistry of domestic animal. $6^{\text {th }}$ edn. San Diego, Elsevier, USA, 2008.

Kasimanickam R, Duffield TF, Foster RA, Gartley CJ, Leslie KE, Walton JS, Johnson WH. Endometrial cytology and ultrasonography for the detection of subclinical endometritis is postpartum dairy cows. Theriogenology, v.62, n.1, p.9-23, 2004.

Lomander H, Gustafsson H, Svensson C, Ingvartsen KL, Frössling J. Test accuracy of metabolic indicators in predicting decreased fertility in dairy cows. J Dairy Sci, v.95, n.12, p.7086-7096, 2012.

Madoz LV, Giuliodori MJ, Migliorisi AL, Jaureguiberry M, Sota RL. Endometrial cytology, biopsy, and bacteriology for the diagnosis of subclinical endometritis in grazing dairy cows. J Dairy Sci, v.97, n.1, p.195-201, 2014.

Martins CFG, Oliveira PM, Nasciutti NR, Barbosa VM, Ferreira MB, Maturana Filho M, Santos RM, Mota FCD, Saut JPE. Avaliação ginecológica e citológica em vacas Holandesas c mais de três repetições de cio. Ciênc Agrárias, v.34, n.6, p.3787-3794, 2013.

Mateus L, Costa LL, Bernardo F, Silva RJ. Influence of puerperal uterine indection on uterine involution and postpartum ovariam activity in dairy cows. Reprod Domest Anim, v.37, n.1, p.31-35, 2002.

McDougall S, Macaulay R, Compton C. Association between endometritis diagnosis using a novel intravaginal device and reproductive performance in dairy cattle. Anim Reprod Sci, v.99, n.1, p.923, 2007.

Meira Jr EBS, Henriques LCS, Sá LRM, Gregory L. Comparison of ultrasonography and histopathology for the diagnosis of endometritis in Holstein-Friesian cows. J Dairy Sci, v.95, n.12, p.6969-6973, 2012.

Nebel, R.L., McGilliard, M.L. Interactions of High Milk Yield and Reproductive Performance in Dairy Cows. J Dairy Sci, v.76, n.10, p.3257-3268, 1993.

Oliveira BM, Arruda RP, Thomé HE, Maturana Filho M, Oliveira G, Guimarães C, Nichi M, Silva LA, Celeghini EC. Fertility and uterine hemodynamic in cows after insemination wich semen assessed by fluorescent probes. Theriogenology, v.82, n.5, p.767-772, 2014.

Opsomer G. Metritis and endometritis in high yielding dairy cows. Rev Bras Reprod Anim, v.39, n.1, p.164-172, 2015.

Peleteiro MC, Marcos R, Santos M, Correia J, Pissarra H, Carvalho T. Atlas de citlogia veterinária. $1^{\text {th }}$ edn. Lisboa, Lidel, Portugal, 2011.

Pleticha S, Drillich M, Heuwieser W. Evaluation of Metricheck device and the gloved hand for the diagnosis of clinical endometritis in dairy cows. J Dairy Sci, v.92, n.11, p.5429-5435, 2009.

Pugliesi G, Rezende RG, Silva JCB, Lopes E, Nishimura TK, Baruselli PS, Madureira EH, Binelli M. Uso da ultrassonografia Doppler em programas de IATF e TETF em bovinos. Belo Horizonte. Rev Bras Reprod Anim, v.41, n.1, p.140-150, 2017.

Pugliesi G, Scolari SC, Mesquita FS, Maturana Filho M, Araújo ER, Cardoso D, Sales JN, Martin I, Sá Filho M, Bertan CM, Binelli M. Impact of probing the reproductive tract during early pregnancy on fertility of beef cows. Reprod Domesti Anim, v.49, n.4, p.e35-e39, 2014.

Silva EB, Fioravanti MCS, Silva LAF, Araújo EG, Menezes LB, Miguel MP, Vieira D. Característica leucocitária, relação albumina/globulina, proteína plasmática e fibrinogênio de bovinos da raça Nelore, confinados e terminados a pasto. Ciênc Rural, v.38, n.8, p.2191-2196, 2008.

Viana JHM, Siqueira LGB. Current status, emerging Technologies, and trends in veterinary ultrasonography applied to cattle reproduction. Spermova, v.7, n.2, p.85-92, 2017.

Williams EJ, Fischer DP, Pfeiffer DU, England GC, Noakes DE, Dobson H, Sheldon IM. Clinical evaluation of postpartum vaginal mucus reflects uterine bacterial infection and immune response in cattle. Theriogenology, v.63, n.1, p.102-117, 2005. 